\title{
O CELULAR NA ESCOLA E O FIM PEDAGÓGICO*
}

\author{
VÂNia Gomes Zuin ${ }^{1}$ \\ Antônio Álvaro SoAres Zuin ${ }^{2}$
}

\begin{abstract}
RESUMO: No mês de novembro de 2017, o governo de São Paulo sancionou a lei que libera a utilização de celulares nas escolas estaduais de ensinos fundamental e médio para fins pedagógicos. Mas, se cada aluno puder acessar as redes sociais durante as aulas, ele será por si só capaz de se concentrar e, assim, controlar o vício da compulsão à conexão? De que modo o professor seria considerado uma figura de autoridade pelos alunos, se cada um deles interrompesse a aula para atender e responder a uma chamada dos pais por meio de seus celulares? Questóes como essas suscitaram os autores a elaborar o seguinte objetivo: refletir criticamente sobre a cultura do aparelho celular e seus desdobramentos na reconfiguraçáo das relaçóes cognitivas e afetivas estabelecidas entre professores e alunos.
\end{abstract}

Palavras-chave: Cultura do aparelho celular. Relação professor-aluno. Educação e Tecnologia. Compulsão à conexão. Choques audiovisuais.

\section{CELL PHONE AT SCHOOL AND THE PEDAGOGICAL END}

ABSTRACT: In November 2017, the government of São Paulo sanctioned the law that frees the use of cell phones in state schools of primary and secondary education for pedagogical purposes. But if each student could access social networks during classes, would he or she alone be able to concentrate and thus control the addiction to compulsively connect him or herself with other people? How could the teacher be considered a figure of authority by students if each of them interrupted the class to answer a call from their parents through their cell phones? Questions such as these led the authors to elaborate the following objective: to reflect critically on the culture of cell phones and its unfolding in the reconfiguration of the cognitive and affective relations between teachers and students.

Keywords: Culture of cell phones. Teacher-student relation. Education and technology. Connection compulsion. Audiovisual shocks.

\footnotetext{
*Este artigo é produto de pesquisas realizadas na Universidade de York, Reino Unido, e na Universidade Federal de São Carlos, Brasil, com apoio da Coordenação de Aperfeiçoamento de Pessoal de Nível Superior (Capes), Fundação de Amparo à Pesquisa do Estado de São Paulo (Fapesp) e Conselho Nacional de Desenvolvimento Científico e Tecnológico (CNPq) (304811/2013-0; 311000/2014-2; 421096/2016-0; 401865/2016-9).

${ }^{1}$ Universidade Federal de São Carlos, Programas de Pós-Graduação em Educaçẫo e Química São Carlos (SP), Brasil. E-mail: vaniaz@ufscar.br

${ }^{2}$ Universidade Federal de São Carlos, Programa de Pós-Graduação em Educação - São Carlos (SP), Brasil. E-mail: dazu@ufscar.br

DOI: 10.1590/ES0101-73302018191881
} 


\title{
LES TÉLÉPHONES PORTABLES DANS LES ÉCOLES ET DES FINS PÉDAGOGIQUES
}

\begin{abstract}
RÉSUMÉ: En novembre 2017, le gouvernement de São Paulo a sanctionné la loi qui libère l'utilisation des téléphones portables dans les écoles publiques d'enseignement primaire et secondaire à des fins pédagogiques. Mais si chaque étudiant peut accéder aux réseaux sociaux pendant les cours, serait-il seul capable de se concentrer et donc de contrôler l'addiction à la contrainte de se connecter? Comment l'enseignant serait considéré comme une figure d'autorité par les élèves si chacun d'eux interrompait la classe pour répondre à un appel de leurs parents à travers leurs téléphones portables? Des questions comme celles-ci ont amené les auteurs à élaborer l'objectif suivant: réfléchir de manière critique sur la culture de l'appareil cellulaire et son déroulement dans la reconfiguration des relations cognitives et affectives établies entre les enseignants et les étudiants.
\end{abstract}

Mots-clés: Culture de l'appareil cellulaire, Relation enseignant-élève, Éducation et technologie, Compulsion à connectivité, Chocs audiovisuels.

\section{Introdução}

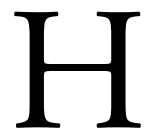

á uma estátua exposta no Museu de Belas-Artes de Leipzig, Alemanha, que ilustra metaforicamente o modo como a capacidade de concentração se dispersa no decorrer das últimas décadas, de maneira cada vez mais corrosiva, mediante o uso das chamadas tecnologias digitais: de autoria do brasileiro Theo Balden (1904-1995), há um homem sentado, aparentemente compenetrado na leitura das notícias de um jornal, cujas páginas são apenas buracos. Trata-se da obra Leitor de jornal (Zeitungsleser). O seu olhar metálico e sem brilho parece procurar, num esforço desesperado, alguma notícia que o sustente nesse mundo real, por meio do imaterial e atemporal. De certo modo, o olhar dessa figura que perpassa as páginas vazadas e nos atinge sintetiza como a concentração se dispersa em tempos das chamadas telas ubíquas, principalmente quando se considera o significado dos aparelhos celulares nas relaçóes cotidianas.

A respeito das relaçóes estabelecidas nos ambientes educacionais, há que se observar o que ocorreu no dia 6 de novembro de 2017: o governador Geraldo Alckmin, do Partido da Social Democracia Brasileira (PSDB), sancionou a lei que liberou a utilização de aparelhos celulares nas escolas estaduais de ensinos fundamental e médio para fins pedagógicos no estado de São Paulo. Essa sanção alterou a Lei no $12.730 / 2007$, que proibia o uso de celulares nas escolas em rela- 
ção a qualquer tipo de uso. Ao defender a revogação da lei vigente desde 2007, o secretário da educação José Renato Nalini afirmou o seguinte: "O ensino prelecional está sendo questionado em todos os ambientes. Se quisermos manter o aluno interessado em aprender, temos de usar a linguagem dele. A linguagem de seu tempo" (NALINI, 2017, p. 1). Preocupado em estimular os alunos a se concentrarem nos conteúdos estudados em sala de aula, o secretário da Educação justifica a ideia da liberação dos celulares nos ambientes escolares como uma necessidade afeita à sociedade atual, pois assim os alunos tenderiam a prestar mais atenção nos conteúdos estudados, na medida em que utilizariam aquele que é o aparelho de seu tempo: o celular.

Com efeito, o aparelho celular pode ser identificado como um gadget que se torna cada vez mais imprescindível não só para os adolescentes, como também para os adultos e até mesmo crianças. Torna-se cada vez mais comum a sensação de que esquecer o telefone móvel em casa significa algo como que se separar de um braço ou de uma perna, como se fosse um membro biônico, tamanha a sua importância nas relaçôes cotidianamente estabelecidas. Atualmente, é quase impossível se separar de tal aparelho, haja vista o fato de cada vez mais pessoas acordarem durante as madrugadas para checar novas mensagens no WhatsApp, nos seus perfis no Facebook, Twitter, Instagram ou Snapchat, ou até mesmo para ler as notícias postadas nos mais variados tipos de sites. É como se o arrefecimento das linhas fronteiriças entre o público e o privado também reverberasse na aproximação cada vez maior entre os estados do sono e de vigília, de modo que, em tempos acelerados (ROSA, 2016), o período de sono precisa ser reduzido em nome do imperativo da "produçáo", que, nesse contexto, se faz presente no compartilhamento contínuo de imagens e comentários por meio do uso das redes sociais (CRARY, 2016). Ou seja, na cultura digital, os distúrbios do sono ocorrem, porque o sono passa ser um distúrbio, por ser caracterizado como algo "improdutivo", off-line.

A ausência de separaçáo entre os estados de sono e vigília pode engendrar, no caso dos estudantes, distúrbios não apenas do sono, como também dificuldades significativas para a manutenção da concentração nos estudos dos conteúdos escolares. Não por acaso, a sensação de ansiedade dissemina-se de tal maneira que se torna quase insuportável, parecendo ser minimamente arrefecida caso se tenha nas mãos algum aparelho que permita a constatação online de que não se está sozinho. Assim, o fato de se comunicar muitas vezes passa a ser mais relevante do que o conteúdo da própria comunicação. Quando o comunicar se transforma, filosoficamente, numa espécie de absoluto, isso significa que se instaura uma contradição quanto à própria comunicação, pois a ansiedade de se sentir sozinho, "desconectado", para usar uma terminologia mais afeita aos tempos presentes, se torna hegemônica em relação ao conteúdo que consiste no fundamento da base do comunicar-se, pois é a reflexão recíproca dos conteúdos comunicados que possibilita a elaboraçấo de novas identidades daqueles que falam e se escutam. 
A possibilidade do estabelecimento de conexóes dos mais variados tipos por meio de tais aparelhos é inédita, fato que remete à reflexão crítica do papel do celular na chamada cultura do aparelho celular (GOGGIN, 2007). Seguindo essa linha de raciocínio, os autores deste artigo têm, como principal objetivo, refletir criticamente sobre a cultura do aparelho celular e seus desdobramentos na reconfiguração das relaçôes cognitivas e afetivas estabelecidas entre professores e alunos. Para que tal finalidade possa ser alcançada, faz-se primeiramente necessário investigar as características da denominada cultura digital e as transformaçóes na atenção advindas do consumo contínuo de choques audiovisuais.

\section{A cultura digital, o choque audiovisual e a distração concentrada}

Quando o computador não mais se limita ao exercício das atividades de trabalho, e se espraia para praticamente todos os lugares e relaçóes, essa máquina nâo mais pode ser identificada somente como instrumento de trabalho; ela se transforma num aparelho multifuncional que permite a realização de

encontros sociais e particulares, processamento e transmissão de dados, a elaboração de atividades de trabalho e de diversão, televisão e comunicação, concentração e dispersão, ser ignorado ou ser percebido, a ponto de todas essas potencialidades se tornarem indiscerníveis entre si (TÜRCKE, 2010, p. 44).

Diante de toda essa multifuncionalidade, também as relaçóes identitárias se transformam radicalmente, a ponto de se desenvolver uma espécie de nova ontologia na sociedade da cultura digital: a de que ser significa ser midiática e eletronicamente percebido em todos os momentos (TÜRCKE, 2010, p. 65). Essa nova ontologia fundamenta-se na necessidade de emitir compulsivamente imagens e comentários nas redes sociais, de modo que se uma existência não for emitida midiática e eletronicamente é como se fosse uma não existência viva. No contexto de transmissão contínua de notícias, principalmente por meio das redes sociais, estabelece-se um imperativo de sobrevivência: torna-se decisiva a captura da atenção, seja por parte das pessoas, seja por parte dos objetos, ou mesmo das pessoas-objetos. Isto é, faz-se preciso propagandear-se a qualquer custo, pois, na medida em que a propaganda se transforma na ação comunicativa por excelência, ela passa a equivaler à própria presença social: "Fazer propaganda de si próprio torna-se um imperativo da autoconservação" (TÜRCKE, 2010, p. 37).

Não que o poder da propaganda, da publicidade, tenha sido instalado apenas no contexto da cultura digital. Já em meados do século passado, Adorno e Horkheimer já haviam afirmado que a "publicidade é o elixir da indústria cultural” (ADORNO \& HORKHEIMER, 1986, p. 151). Ou seja, já no capitalismo monopolista havia a necessidade premente de se fazer com que as mercadorias, in- 
clusive as culturais, se distinguissem umas das outras, ainda que tal distinção fosse ilusória por se basear em detalhes que eram propagandeados como se fossem atributos exclusivos de tais mercadorias. Contudo, na atual sociedade do capitalismo transnacional, o ato de se propagandear adquire a condição de autoconservação.

Seguindo essa linha de raciocínio, há um fio condutor que se faz presente nas mais variadas situaçóes atuais: os empregados ou desempregados que exibem seus currículos nas páginas do Facebook ou do LinkedIn; as pessoas que filmam com seus celulares partes íntimas do corpo e as postam no YouTube ou em outro veículo, com o objetivo de receber o maior número possível de likes; os adolescentes que se tornam e desejam ser youtubers, hoje um ideal de profissão ou ocupação (um digital influencer), que normalmente narram suas intimidades, de forma que, dependendo do número de visualizaçóes e comentários, são contratados pelo próprio YouTube para que suas imagens "descoladas" sejam associadas a propagandas de produtos afeitos a tais imagens; os professores que transmitem vídeo-aulas nos seus canais no YouTube, os quais também se transformam em youtubers; os professores universitários que, em muitas ocasiôes, assumem os custos de publicar seus artigos em periódicos internacionais na forma do open access journals, de tal maneira que quaisquer pessoas possam acessá-los sem ter de pagar tal acesso à editora. Ao agirem dessa forma, os professores tornam-se cada vez mais visíveis, uma vez que seus artigos são mais acessados, ao passo que adquirem mais chances de serem citados em outros trabalhos e receber mais recursos financeiros das agências de fomento à pesquisa. Não por acaso, os denominados produtos acadêmicos precisam ser cada vez mais exibidos, de modo que tal exibição pode ser observada tanto no currículo da Plataforma Lattes, do Conselho Nacional de Desenvolvimento Científico e Tecnológico (CNPq), quanto na Fundação de Amparo à Pesquisa do Estado de São Paulo (FAPESP), que solicita ao pesquisador, concorrente a determinado recurso, que informe em sua súmula curricular o número de citaçóes e fatores de impacto de seus trabalhos disponibilizados pelo Google Acadêmico, por exemplo (ZUIN \& ZUIN, 2011; 2014; 2016).

Todas essas situaçóes são exemplo do que significa a imposição da lógica da propaganda como condição de autoconservação em todas as esferas sociais, fato que remete à análise de um fator decisivo para a sua onipresença atual: a disseminação cada vez maior dos aparelhos celulares. Antes de aprofundar a análise das consequências de tal disseminação, é relevante destacar as transformaçóes na forma de percepção e atenção decorrentes do consumo dos choques imagéticos, tendo em vista que os computadores náo mais permanecem espacialmente restritos na condição de computadores de mesa e se espraiam no formato de computadores de bolso - caso dos celulares. $\mathrm{Na}$ ocasiáo do ano de $2002^{1}$, data da publicação na Alemanha do livro Sociedade excitada: filosofia da sensação, Christoph Türcke salientou como o consumo contínuo de choques audiovisuais, transmitidos por meio das telas ubíquas, desenvolveu o fenômeno da distração concentrada: "De modo fulminante, o choque concentra a aten- 
ção num ponto, para poder triturar essa concentração através de incontáveis repetiçóes. O meio de concentração é, propriamente, o meio de decomposição" (TÜRCKE, 2010, p. 266).

A orientação do sensório, proporcionada pelo consumo do choque audiovisual, consiste em uma desorientação, pois tal choque "concentra a atenção num ponto, para poder triturar essa concentração através de incontáveis repetições" (TÜRCKE, 2010, p. 266). Esse é o fenômeno da distração concentrada, uma vez que a capacidade de atenção é imediatamente voltada para que ocorra a concentração de determinado choque, mas, como os choques continuamente se alternam, essa concentração não consegue permanecer atrelada ao estímulo audiovisual o tempo necessário para que sejam elaboradas representaçôes mentais duradouras, ou, em outras palavras, conceitos.

Diariamente, são delineadas incontáveis distraçôes que se concentram apenas por instantes, nas, por assim dizer, "picadas audiovisuais". Daí o comportamento decorrente de vício que se desenvolve, mediante o consumo e a exibição dessas "picadas" cada vez mais potentes e sedutoras, já que o prazer do consumo deriva, em muitas situações, de sensaçóes de onipotência sadonarcísica. Nesse sentido, dificilmente se observam diálogos entre os usuários do Facebook, mas sim as atitudes de se impor tanto uma felicidade muitas vezes fake quanto o próprio ponto de vista exibido de forma agressiva e irredutível. A repetição contínua das distraçóes concentradas provoca transformaçóes radicais na própria capacidade de simbolizaçáo, e tal capacidade é identificada como um dos fundamentos do processo de humanização. $\mathrm{Na}$ expressão de Lash e Lury (2007), é na sociedade da indústria cultural global que acontece o processo de canibalização do simbólico, pois, em meio às imagens hiperreais digitais — imagens estas selecionadas após o uso de filtros de todas as ordens que tornam qualquer figura mais brilhante, sem dobras, rugas ou marcas do tempo - , as representações mentais e todo o esforço, inclusive físico, de elaborá-las empalidecem diante do poderio das imagens digitais que não se subordinam ao real, porém que o manipulam. É como se as imagens não só pensassem como também fornecessem as diretrizes de comportamento, de tal forma que a significação instrumentalmente se transforma cada vez mais em algo operacional, ao se consubstanciar com "o próprio fazer, com o impacto" (LASH \& LURY, 2007, p.12).

Se de fato cada vez mais se alastra o processo de canibalização da esfera simbólica, são produzidas consequências decisivas em todas as esferas de relacionamento humano. Numa frase profética, Türcke asseverou o seguinte: "A tela, o grande recheio do tempo livre, penetrou profundamente, por meio do computador, no mundo do trabalho; a coordenação de processos inteiros de produção e administração perpassa por ela, de tal modo que se apresenta como o ensino do futuro" (TÜRCKE, 2010, p. 266-267). Ao que tudo indica, esse ensino do futuro já se tornou imageticamente presente na tela ubíqua do aparelho celular. 


\section{A escola e a concentração dispersa: meios e fins pedagógicos síncronos, assíncronos e para além}

Determinadas expressōes adquirem um significado muito maior com o passar do tempo. No caso da relação indivíduo e computador, uma dessas expressôes pode ser a chamada tela de descanso. Muito utilizada no que se refere aos computadores de mesa, a tela de descanso era um programa de computador que preenchia a tela, geralmente com animaçóes, enquanto a máquina não estava operando, com o propósito de evitar a queima de fósforo. Com o passar do tempo, percebeu-se que o descanso não era tanto da máquina, mas sim da pessoa que se afastava do contato com os choques audiovisuais e tinha, portanto, a possibilidade de tranquilizar, mesmo que por pouco tempo, seu sistema sensório-perceptivo. Essa mesma pessoa poderia se afastar de seu computador de mesa e ligar a televisão para poder amainar a ansiedade decorrente do vício de consumo desses choques, contudo a exemplo do computador de mesa, a televisáo permanecia no espaço que lhe fora designado. Nem ela nem o computador acompanhavam seu proprietário quando ele ou ela saíam de casa. E mesmo se as pessoas pudessem levar os choques audiovisuais consigo por meio de notebooks, haveria momentos em que as próprias telas de descanso de tais aparelhos começariam a agir.

Porém, essa situação transformou-se de forma radical com a propagação dos celulares, principalmente com a introdução no mercado do IPhone, em 2007. Esse fato foi revolucionário, sendo um desdobramento da revolução microeletrônica de 1980, pois foi nesse momento que o celular não mais se limitou a ser um aparelho telefônico, mas sim passou a ser um computador de bolso com as mais variadas funçóes e aplicabilidades que se tornaram disponíveis principalmente pelo acesso à internet. Assim, por meio do celular, o vício pelo consumo contínuo de estímulos audiovisuais atingiu um patamar incomparável no que tange aos chamados computadores de mesa ou notebooks. Graças à sua portabilidade, esse computador de bolso acompanha seu usuário em quaisquer tempos e espaços, de tal modo que o indivíduo pode permanecer o tempo todo conectado, pois o "design técnico-econômico do celular" (STEINMAURER, 2016, p. 140) lhe permite efetuar tal conexão. A expressão design técnico-econômico é adequada, sobretudo pelo fato de, por intermédio do design do celular, o seu portador poder tanto se conectar com as gigantes do mercado digital, tais como a Apple, a Amazon e o Google, quanto por elas ser conectado, ou melhor, vigiado. Náo por acaso, os atuais estudos e pesquisas sobre as consequências de tais mobilidades e conexões já suscitam o advento da expressáo conceitual cultura do aparelho celular (GOGGIN, 2007; GREENFIELD, 2017).

Atualmente, não são apenas os adolescentes que não conseguem mais se separar de seus aparelhos celulares, mas sim qualquer pessoa. Esse fato está fomentando modificaçôes estruturais em relação à produção e disseminação das 
informações, à capacidade de concentração e à produção da memória, sobretudo a respeito das maneiras como as informaçóes são lembradas ou esquecidas. Tal como foi destacado anteriormente, já em 2002 Türcke observava a presença, cada vez mais constante, do fenômeno da distração concentrada. Ora, a repetição contínua das distraçóes concentradas parece ter produzido, no transcorrer dos últimos anos, uma mudança estrutural na capacidade de focalizar a atençâo em determinada informação audiovisual, produzindo assim a chamada concentração dispersa na sociedade da cultura do aparelho celular. Diante do atual bombardeamento dos estímulos audiovisuais, os quais são consumidos continuamente principalmente pelo uso dos celulares, a dispersão da concentração não se torna uma espécie de consequência, mas sim transforma-se numa parte da "essência" da concentração; trata-se de uma essência mediada historicamente pelo vício de consumo constante de tais estímulos.

Em referência à esfera educacional, tal vício não pode ser exclusivamente imputado aos alunos, que cada vez mais utilizam seus celulares dentro e fora das escolas, mas também aos próprios professores. Já há situaçóes em que professores universitários se sentam nas cadeiras do fundo da sala de aula e acessam a seus perfis no Facebook por meio de seus celulares, em vez de se concentrarem nas falas dos alunos que expóem suas consideraçóes sobre dado tema durante seminários. Ou seja, nem mesmo os professores conseguem resistir ao apelo angustiante de checar a todo tempo se possuem novas mensagens ou notificaçôes de internautas que "curtiram" ou não suas postagens nas redes sociais, em qualquer nível de ensino e pesquisa.

Não é fortuito o fato de que a utilizaçáo das redes sociais, por parte dos alunos e professores, para a realização de finalidades pedagógicas, produz controvérsias entre os pesquisadores. No caso específico do Facebook, observam-se dilemas quando se trata do emprego de tais recursos tecnológicos para o desenvolvimento de atividades pedagógicas. Hew (2011) publicou um artigo no qual analisa os resultados de pesquisas produzidas em vários países sobre o uso de aparelhos eletrônicos, tais como os celulares, com o propósito de acessar o Facebook nas salas de aula. A conclusão desse pesquisador foi a de que os estudantes, em geral, utilizam muito pouco o Facebook para fins pedagógicos, pois, na maior parte do tempo, permanecem em comunicaçáa com pessoas conhecidas e expóem perigosamente dados pessoais. Em decorrência do desejo de se expor eletrônica e midiaticamente, como condição para a autoconservação identitária, tanto professores (BATHON \& BRADY, 2010) quanto os alunos (LIVINGSTONE, 2008) podem de forma massiva postar informaçóes comprometedoras de si próprios. Atualmente, a compulsão de se emitir midiática e eletronicamente parece ser efetiva na medida em que se consubstancia com outra compulsão que provém principalmente do uso contínuo do celular: a da conexão permanente.

Muito provavelmente, a crescente ansiedade, já diagnosticada por profissionais da saúde mental (SPITZER, 2014), deriva-se da necessidade imperativa 
de se sentir conectado a qualquer custo. Nesse sentido, tornam-se cada vez mais comuns os casos dos professores que compartilham com seus alunos os textos de suas respectivas disciplinas e as informaçôes de suas vidas particulares por meio dos seus perfis em diversas redes sociais, o que acarreta uma ruptura inédita entre os limites das esferas privada e pública também na dimensão educacional. Talvez ainda seja cedo para avaliar as consequências de tal ruptura no âmbito pedagógico, mas isso náo impede que sejam expostas questóes tais como:

- De que modo o professor poderá avaliar seus alunos, se estes são seus "amigos" em redes sociais?

- De que forma a autoridade do professor é, por assim dizer, reconfigurada nessa situaçáo de ruptura das esferas privada e pública?

- Que mensagens ou conteúdos estão e serão transmitidos por meio das redes sociais?

São questóes como as expostas que evidenciam, em muitas ocasióes, o quáo professores e alunos estão se transformando mediante o processo de elaboração de novas identidades digitais. Durante esse processo, dão-se também práticas de violência inéditas, como, por exemplo, a realização de práticas de cyberbullying de alunos contra professores ou outras formas de expressão que demandam mais atenção (ZUIN, 2017).

Embora se trate de um fenômeno mundial, o Brasil destaca-se como um dos principais países entre os quais os alunos, principalmente de ensino médio, gravam, com seus celulares, imagens de professores sendo humilhados em situações de sala de aula e as postam em plataformas digitais como o YouTube. A maior parte dos comentários das pessoas que acessam a essas imagens é de ordem pejorativa em relação à profissão de ensinar. A seguir, será analisada uma dessas postagens. Antes da análise, é relevante enfatizar que o professor e o aluno não serão identificados. De forma geral, os pesquisadores asseveram que a investigação dos dados de tais redes sociais possibilita uma "oportunidade única para se estudar as comunidades emergentes e as culturas" (FLICKER; HAANS; SKINNER, 2004, p. 131-132), contudo há também a concordância de que se deve trabalhar com o escopo de evitar a identificação dos que postam tais imagens e comentários. Daí a importância de que sejam alterados, no caso de divulgação dos resultados da pesquisa, os possíveis nomes dos responsáveis por tais postagens (FLICKER; HAANS; SKINNER, 2004; KONIJ; VELDHUIS; PLAISIER, 2013; BAUMAN $\&$ BELLMORE, 2015).

Feitas essas consideraçóes, eis uma descrição das imagens e dos comentários do vídeo em questão. Postado no YouTube em 2016, com duração de 42 segundos e visto 983.142 vezes até o presente momento, o vídeo refere-se à se- 
guinte situação: na sala de aula, um professor está lendo as mensagens ou alguma notícia em seu aparelho celular, enquanto os alunos de uma escola do ensino médio gritam sem parar. Não se sabem quais são os motivos de tamanha balbúrdia, e, aparentemente, o professor não esboça a mínima reação diante da gritaria dos alunos. Um dos alunos que está gravando todas as imagens comenta o seguinte: "Olha que coisa linda!".

Subitamente, um aluno sentado numa cadeira da última fileira da classe levanta-se, pega um ventilador e atira-o na direção do professor. $O$ ventilador atinge a lousa, e o professor para de olhar seu celular. Enquanto isso, o aluno que está registrando toda a situação, e que posteriormente se tornará o autor do cyberbullying, aos risos exclama um palavrão. Logo em seguida, o aluno que arremessou o ventilador póe sua mochila nas costas e, sem dizer uma só palavra, sai calmamente da sala de aula. Já o professor se dirige até o corredor e, com seu celular, filma o aluno que atirou o ventilador. Já o autor do cyberbullying afirma: "O aluno $\mathrm{X}$ está sendo gravado!", ao mesmo tempo em que outra aluna diz: "Gente do céu!".

$\mathrm{Na}$ análise dessas imagens e dos comentários feitos pelos participantes do vídeo surge a seguinte questão: quais são as razões que fizeram com que o professor se comportasse dessa forma? Ou seja, por que o professor não interrompeu a gritaria dos alunos nem dialogou com eles e elas sobre as causas desse tipo de barbárie se fazer presente na sala de aula? Talvez uma das explicaçóes pudesse ser a seguinte: cansado de ter de repreender os alunos que utilizam seus celulares durante as aulas para fins não pedagógicos, o professor teria se revoltado e procedido do mesmo modo que os alunos e as alunas, numa espécie de protesto silencioso, pois seria o silêncio do protesto que contrastaria com o barulho ensurdecedor dos alunos e das alunas, os quais aproveitariam essa chance para poder gritar sem serem interrompidos pelo professor.

É interessante notar que o aluno que arremessa o ventilador na direção do professor pareceu se preocupar em não atingi-lo, mas procedeu assim para poder capturar a atenção dele, uma vez que o educador olhava fixamente seu celular. Porém, o próprio docente talvez não imaginasse que o aluno reagiria tão violentamente. Nessa reaçáo violentíssima do aluno, desvela-se o seu ressentimento de que o desinteresse do professor consiste, possivelmente, em uma atitude cotidianamente presente na relaçáo que se estabelece entre ambos. Entretanto, na medida em que o professor demonstra sarcasticamente esse desinteresse, o aluno como que se sente no direito de se expor seu ressentimento, que fora retroalimentado em uma reação furiosa. É como se o aluno exclamasse a seguinte frase: "Como o professor ousa mostrar seu desinteresse, que também é o nosso, de forma tão explícita?"

Ao refletir sobre a tresvaloração de valores realizada pelos sacerdotes judeus, que passam a valorizar a dor e o sofrimento em detrimento da força e da potência compreendidas como virtudes, Nietzsche salienta que tal rebelião escrava na moral sufoca a manifestação da força física, pois toma forma "o ressentimento 
dos seres aos quais é negada a verdadeira reaçáo, a dos atos, e que apenas por uma vingança imaginária obtêm reparação" (NIETZSCHE, 1998, p. 28). Não se trata mais de uma vingança imaginária quando o aluno arremessa um ventilador na direção do professor, mesmo que seja para assustá-lo. Mas foi o ressentimento vicejado continuamente em relaçáo ao professor que preparou o terreno fértil para que o ódio fosse fisicamente exposto. Já o professor, quando grava com seu celular a imagem do aluno que lançou o ventilador em sua direçáo, se iguala ao próprio aluno que registrou todas as imagens e cometeu o cyberbullying. Além disso, por meio desse ato, o professor legitima todos os alunos e alunas a proceder da mesma forma com seus celulares, caso ocorra uma situaçáo semelhante no futuro. Ele sabe também utilizar seu celular como "arma" que registra e dispara potentes projéteis audiovisuais. Aliás, ambos, professores e alunos, sabem bem como usar seus celulares como máquinas bélicas de imagens.

Diante do quadro da concentraçáo dispersa e do cyberbullying contra professores, torna-se pertinente a seguinte pergunta: os celulares não poderiam ser efetivamente utilizados para fins pedagógicos? Há pesquisas realizadas no Brasil, e em vários outros países, cujos resultados apontam para possíveis benefícios obtidos pelo uso de aparelhos celulares e tablets nas salas de aula. São tais os benefícios:

- em relaçáo ao engajamento dos estudantes, tendo em vista que se sentem mais motivados a participar das aulas (THOMAS; O'BANNON; BOLTON, 2013);

- no desenvolvimento e na aquisição de novos conhecimentos por meio do uso de aplicativos e softwares educacionais (BATISTA \& BARCELOS, 2013; FONSECA, 2013; MAGUTH, 2013; KIM et al., 2017);

- na utilização dos recursos de imagens e sons das câmeras digitais, inclusive dos aparelhos celulares (WEBB, 2013);

- na maior aproximação entre professores e alunos (MAZER; MURPHY; SIMONDS, 2007; LONN \& TEASLEY, 2009);

- entre outros.

Não há como negar os benefícios decorrentes do uso de celulares e de outros aparelhos, tais como laptops, tablets e notebooks, no transcorrer das atividades desenvolvidas em salas de aula. Suponha-se, por exemplo, que um professor de filosofia esteja dialogando com seus alunos sobre as relaçôes entre os conceitos e as posturas éticas e se lembre do quadro renascentista $A$ Escola de Atenas. Nessa obra-prima de Rafael há, entre outros elementos, as figuras de Platão, que, ao segurar o Timeu, aponta para cima, destacando a dimensão das ideias e as essências dos conceitos, ao passo que Aristóteles, que segura a sua obra Ética a Nicômaco e direciona sua mão no sentido horizontal, lembra que o mundo sensível produz 
o desejo, sendo este considerado o pai do conceito. Ora, esse mesmo professor poderia utilizar o celular para acessar a Iinternet e projetar essa imagem para que todos pudessem conjuntamente analisá-la. Além disso, poderia ser feita uma visita virtual a um museu que disponibilizasse tal acesso e interação.

Não fosse o auxílio do emprego dos celulares, mediante o qual a imagem de $A$ Escola de Atenas seria acessada, o professor teria de muito provavelmente esperar ao menos uma semana para poder levar um livro com a imagem desse quadro de Rafael e discuti-la com os alunos. Ou seja, se o professor promovesse tais acessos orientados e permanecesse com os seus alunos, quando ambos saíssem virtualmente do espaço físico da sala de aula, várias relaçôes conceituais poderiam ser elaboradas por tais agentes educacionais e não se perderiam nesse intervalo espaçotemporal de sete dias (SJÖSTRÖM et al., 2017).

É relevante enfatizar que, nesse caso, a comunicaçáo secundária, propiciada pelo uso de celulares e afins, se tornaria elemento-chave para o desenvolvimento da comunicação primária entre professores e alunos, na medida em que, física e espiritualmente, esses agentes educacionais estivessem juntos. Se os alunos espiritualmente "saíssem" por meio do uso dos seus celulares e acessassem às redes sociais para conversar sobre assuntos alheios aos conteúdos estudados em sala de aula, haveria um sério prejuízo no desenvolvimento do processo de ensino e aprendizagem. Se o professor espiritualmente "saísse" sozinho e acessasse a sua conta no Facebook no fundo da sala durante os seminários apresentados pelos alunos, também ocorreria um dano decisivo nesse mesmo processo. Mas se ambos, professores e alunos, "saíssem" juntos, pelo celular ou por outro aparelho eletrônico, acessassem à internet e voltassem juntos para a sala de aula para discutir os conteúdos trabalhados, então se daria uma possibilidade real de que o virtual fosse utilizado para, na expressão de Adorno, fomentar um novo "contato corporal com as ideias" (ADORNO, 2010, p. 21).

Não que seja recente o fato de os alunos estarem fisicamente presentes nas salas de aula e, concomitantemente, fora dela com o pensamento voltado para quaisquer outros assuntos. Não foi na sociedade da cultura digital que esse tipo de distração se originou, no entanto é na cultura digital que se espraia o fenômeno da concentração dispersa, de modo que não só alunos, como também professores, muitas vezes náo resistem ao vício da compulsão à conexáo e, mesmo em sala de aula, se "desconectam" entre si quando conversam com outras pessoas pelas redes sociais e cessam de dialogar conjuntamente acerca dos conteúdos que deveriam estar sendo estudados.

Essa situação, inevitavelmente, suscita os seguintes questionamentos em relação à lei paulista, em cujo texto se lê a liberação do uso de celulares nas salas de aula para fins pedagógicos:

- Perante a presença cada vez maior do vício da compulsão à conexáo, não haveria o quadro ideal para que professores e alunos tivessem dificuldades para mutuamente se concentrar nos conteúdos estudados?; 
- Será que os usos de celulares e as capacidades de autocontrole não difeririam entre os alunos dos ensinos fundamental e médio?;

- Não seria absolutamente necessário elaborar condiçóes específicas para o uso de celulares em relação aos alunos de ensino fundamental e outras para os do ensino médio?;

- De que modo os professores e as professoras ainda seriam considerados(as) figuras de autoridade, se os alunos pudessem interromper a aula para atender a alguma chamada dos pais, ou mesmo se respondessem a tal chamada pelo WhatsApp?;

- $\quad$ E a questão mais importante: se os alunos pudessem acessar as redes sociais durante as aulas por meio de seus celulares, eles ou elas seriam por si só capazes de se concentrar e, assim, controlar o vício da compulsão à conexão?

Essas questôes ainda estão sem respostas, haja vista o ineditismo da situação, mas já preocupam os agentes educacionais, que sentem na própria pele as consequências reais da presença ubíqua do virtual.

\section{Conclusão}

Atualmente, recrudescem as publicaçôes de pesquisas no Brasil e no exterior sobre os usos de aparelhos eletrônicos digitais entre professores e alunos dentro e fora das salas de aula. Tal como foi anteriormente observado, há vários pesquisadores que destacam elementos positivos e negativos relacionados aos usos de tais aparelhos, notadamente os celulares. A liberação do uso de celulares nas escolas fundamentou-se no anelo de que fossem incrementados os elementos positivos pertinentes às finalidades pedagógicas. E, talvez, o mais importante benefício, de acordo com as palavras do secretário da Educação, refira-se ao seguinte desejo: "Se quisermos manter o aluno interessado em aprender, temos de usar a linguagem dele. A linguagem de seu tempo" (NALINI, 2017, p. 1). Ou seja, a manutenção do interesse do aluno, no que tange ao aprendizado dos conteúdos das matérias nas salas de aula, deve ser estimulada pelo uso dos aparelhos celulares. Mas esses mesmos celulares podem inaugurar uma situação de descontrole, principalmente pela possibilidade de a concentração dispersa e também de o cyberbullying se espraiarem ainda mais dentro e fora das salas de aula. Se isso ocorrer, em vez dos fins pedagógicos, haverá o fim do pedagógico, cujos efeitos começam a ser observados até mesmo nas crianças, que são cada vez mais diagnosticadas como portadores de déficit de atenção.

Perante o contexto de bombardeamento constante de choques audiovisuais, torna-se significativa a expressão de Türcke de que já se têm indí- 
cios da presença da denominada cultura do déficit de atenção, de tal modo que "especialmente indefesas são crianças que, muito antes de poder entender o que se passa nas telas, tiveram a oportunidade de perceber a força de sua cintilação como privação elementar da atençâo" (TÜRCKE, 2016, p. 76). Apesar da seduçáo da portabilidade e de todas as operaçóes e aplicativos que lhe são facultados por ser um computador de bolso, o celular não pode ser instrumentalmente utilizado como se pudesse ser idealisticamente apartado do contexto social no qual se insere.

Antes mesmo da existência dos celulares, Marcuse (1999) já havia enfatizado o fato de que a tecnologia não pode ser caracterizada somente como um conjunto de técnicas, mas sim como um processo social afeito às contradiçôes das relações humanas responsáveis pela sua confecção. Sendo assim, o atual processo de digitalização das relações humanas deve ser compreendido como um processo que "atua na relação entre a institucionalização e o social, entre o indivíduo e a socialização, entre o epistêmico e o ontológico" (ALLERT; ASMUSSEN; RICHTER, 2017, p. 31).

Em outras palavras, não é possível isolar o uso do aparelho celular como se simplesmente o emprego per se de tal aparelho já garantisse a obtenção imediata de seus potenciais benefícios. Por mais que sejam alentadoras as possibilidades de uso desses computadores de bolso, é preciso investigar criticamente o modo como o ethos da cultura digital se encontra mediado no celular e, portanto, a forma como a concentraçáo dispersa e as práticas como o cyberbullying ou o isolamento social dos considerados diferentes e, portanto, aparentemente desprezíveis, se propagam cada vez mais, até porque os alunos já utilizavam tais máquinas antes mesmo que fossem legalmente liberadas nas escolas. Importa refletir sobre o olhar para além do dispositivo, quaisquer que sejam seus formatos, como nos lembra Theo Balden em sua obra $O$ Leitor de Jornal. As páginas agrupadas parecem uma sucessão de vazios grossos, cujas saliências apresentam ora mais ora menos brilho, um farfalhar que pretende prender a atenção a qualquer custo.

Por mais que as capacidades de divisão da atenção dos alunos possam ser enaltecidas, no decorrer da produção das chamadas multitarefas - as quais já são um exemplo do modo como recrudesce a quantidade de açôes que devem ser produzidas na sociedade da aceleração do tempo de vida (ROSA, 2016) —, há que se considerar o fato de que é em comunidade que as práticas de atençâo se desenvolvem. $\mathrm{Na}$ sociedade da cultura digital, cujas multidóes solitariamente se conectam, seria preciso fazer com que a compulsão à conexão e o cyberbullying fossem criticados e combatidos nos ambientes escolares. Se fosse assim, os alunos e professores empregariam a própria tecnologia digital para que outros tipos de conexôes pudessem ser comunitariamente elaborados e usufruídos. 


\section{Notas}

1. Publicado na Alemanha em 2002 pela Verlag C. H. Beck, o título original do livro é Erregte gesellschaft: philosophie der sensation. Sua tradução para a língua portuguesa foi publicada em 2010, pela editora da Universidade Estadual de Campinas (UNICAMP).

\section{Referências}

ADORNO, T.W. Teoria da semiformação. In: PUCCI, B.; ZUIN, A.A.S.; LASTÓRIA, Luiz A.C.B. (Orgs.). Teoria critica e inconformismo: novas perspectivas de pesquisa. Campinas: Autores Associados, 2010.

ADORNO, T.W. \& HORKHEIMER, M. Dialética do esclarecimento: fragmentos filosóficos. 2. ed. Rio de Janeiro: Jorge Zahar, 1986.

ALLERT, H.; ASMUSSEN, M.; RICHTER, C. Digitalitätund selbst: Interdisziplinaräre Perspektiven auf Subjektivierungs - und Bildungsprozesse. Bielefeld: Transcript Verlag, 2017.

BATHON, J.M. \& BRADY, K.P. Teacher free speech and expression in a digital age: a legal analysis. Nassp Bulletin, v. 94, p. 213-226, 2010. https://doi. org/10.1177/0192636510387823

BATISTA, S.C. \& BARCELOS, G.T. Análise do uso do celular no contexto educacional. Renote, Porto Alegre, v. 11, n. 1, p. 1-10, 2013. http://dx.doi.org/10.22456/16791916.41696

BAUMAN, S. \& BELLMORE, A. New directions in cyberbullying research. Journal of School Violence, v. 14, n. 1, p. 1-10, 2015. https://doi.org/10.1080/15388220.2014.968281

CRARY, J. Capitalismo tardio e os fins do sono. São Paulo: Ubu, 2016.

FLICKER, S.; HAANS, D.; SKINNER, H. Ethical dilemmas in research on Internet communities. Qualitative Health Research, v. 14, n. 1, p. 124-134, 2004. https://doi. org/10.1177/1049732303259842

FONSECA, A.G.M.F. Aprendizagem, mobilidade e convergência: Mobile Learning com Celulares e Smartphones. MidiaEcoTidiano, Rio de Janeiro, v. 2, p. 265-283, 2013. https://doi.org/10.22409/ppgmc.v2i2.42

GOGGIN, G. Cell phone culture: mobile technology in everyday life. Londres e Nova York: Routledge, 2007.

GREENFIELD, A. Radical technologies: the design of everyday life. Londres: Verso, 2017.

HEW, K.F. Students' and teachers' use of Facebook. Computers in Human Behaviour, v. 27, p. 662-676, 2011. https://doi.org/10.1016/j.chb.2010.11.020

KIM, I.; JUNG, G.; JUNG, H.; KO, M.; LEE, U. Let's FOCUS: Mitigating Mobile Phone Use in College Classrooms. Interactive, Mobile, Wearable and Ubiquitous Technologies, v. 1, n. 3, p. 1-29, 2017. https://doi.org/10.1145/3130928 
KONIJ, E.A.; VELDHUIS, J.; PLAISIER, X.S. YouTube as a research tool: three approaches. Cyberpsychology, Behaviour and Social Networking, v. 16, n. 9, p. 695-701, 2013. https://doi.org/10.1089/cyber.2012.0357

LASH, S. \& LURY, C. Cultural global industry. Cambridge: Polity, 2007.

LIVINGSTONE, S. Taking risky opportunities in youthful content creation: teenagers' use of social networking sites for intimacy, privacy, and self-expression. New Media Society, v. 10, p. 393-411, 2008. https://doi.org/10.1177/1461444808089415

LONN, S. \& TEASLEY, S. Podcasting in higher education: What are the implications for teaching and learning? Internet and Higher Education, v. 12, p. 88-92, 2009. https://doi. org/10.1016/j.iheduc.2009.06.002

MAGUTH, B.M. The educative potential of cell phones in the social studies classroom. The Social Studies, v. 104, n. 2, p. 87-91, 2013. https://doi.org/10.1080/00377996.2 012.655347

MARCUSE, H. Tecnologia, guerra e fascismo. São Paulo: Editora da Unesp, 1999.

MAZER, J.P.; MURPHY, R.E.; SIMONDS, C. I'll see you on "Facebook": The effects of computer-mediated teacher self-disclosure on student motivation, affective learning, and classroom climate. Communication Education, v. 56, n. 1, p. 1-17, 2007. https://doi. org/10.1080/03634520601009710

NALINI, J.R. Aprovada a lei que libera o uso de celular nas escolas estaduais de São Paulo. 2017. Disponível em: <http://www.educacao.sp.gov.br/noticias/aprovada-lei-que-liberao-uso-do-celular-em-escolas-estaduais-de-sp/>. Acesso em: 22 jan. 2018.

NIETZSCHE, F. Genealogia da moral. São Paulo: Companhia das Letras, 1998.

ROSA, H. Beschleunigung: die Veränderung der Zeitskulturen in der Moderne. Franfkfurt am Main: Suhrkamp Verlag, 2016.

SJÖSTRÖM, J.; EILKS, I.; ZUIN, V.G. Towards eco-reflexive science education: a critical reflection about educational implications of Green Chemistry. Science \& Education, v. 25, p. 1-21, 2016.

SJÖSTRÖM, J.; FRERICHS, N.; ZUIN, V.G.; EILKS, I. Use of the concept of Bildung in the international science and environmental education literature. Studies in Science Education, v. 53, p. 165-192, 2017. https://doi.org/10.1080/03057267.2017.1384649

SPITZER, M. Digitale Demenz: wie wir uns und unsere Kinder um den Verstand bringen. München: Droemer Verlag, 2014.

STEINMAURER, T. Permanent Vernezt: zur Theorie und Geschichte der Mediatisierung. Stuttgart: Springer Verlag, 2016.

THOMAS, K.M.; O'BANNON, B.W.; BOLTON, N. Cellphones in the classroom: Teachers' perspectives of inclusion, benefits, and barriers, Computers in the Schools: Interdisciplinary Journal of Practice, Theory, and Applied Research, v. 30, n. 4, p. 295-308, 2013. https://doi.org/10.1080/07380569.2013.844637

TÜRCKE, C. Erregte Gesellshaft: Philosophie der Sensation. München: C. H. Beck Verlag, 2002. 
TÜRCKE, C. Hiperativos! Abaixo a cultura do déficit de atenção. Rio de Janeiro: Paz e Terra, 2016. . Sociedade excitada: filosofia da sensação. Campinas: Editora da Unicamp, 2010.

WEBB, C.L. Cell phones in the classroom: don't put them away just yet. Kapp Delta Pi Record, v. 49, p. 180-183, 2013. https://doi.org/10.1080/00228958.2013.845508

ZUIN, A.A.S. Cyberbullying contra professores: dilemas da autoridade dos educadores na era da concentração dispersa. São Paulo: Edições Loyola, 2017.

ZUIN, V.G.; ZUIN, A.A.S. A formação no tempo e no espaço da Internet das Coisas. Educação e Sociedade, v. 37, p. 757-773, 2016. http://dx.doi.org/10.1590/es010173302016167198

ZUIN, V.G.; ZUIN, A.A.S. Indústria Cultural digital e a revolução microeletrônica. In: PUCCI, B. (Org.). Teoria Crítica da cultura digital: aspectos educacionais e psicológicos. São Paulo: Nankim, 2014. v. 1. p. 1-12.

ZUIN, V.G.; ZUIN, A.A.S. Professores, tecnologias digitais e a distração concentrada. Educar em Revista, v. 42, p. 213-228, 2011. http://dx.doi.org/10.1590/S010440602011000500014

Recebido em 21 de fevereiro de 2018.

Aceito em 1 de abril de 2018. 